
ISSN: 2085-3653| e-ISSN: 2549-3116 https://jurnal.unimed.ac.id/2012/index.php/jpk https://jurnal.unimed.ac.id

\title{
The effectiveness of the four-step jigsaw and jigsaw learning model in improving students' argumentation skills about salt hydrolysis concept
}

\author{
Windy Kartika ${ }^{1}$, Asrial ${ }^{2}$ and Muhammad Haris Effendi-Hasibuan ${ }^{2, *}$ \\ ${ }^{1}$ Chemistry Education Study Program, Postgraduate, Jambi University, Jambi 36361, Indonesia \\ ${ }^{2}$ Department of Chemistry Education, Jambi University, Jambi 36361, Indonesia \\ *Corresponding author: MHEH, hariseffendi@unja.ac.id
}

DOI: 10.24114/jpkim.v13i3.29929

Article history:

Received: 26 November 2021

Revised: 01 December 2021

Accepted: 02 December 2021

\begin{abstract}
One of the learning models that can train students in developing argumentation skills is the jigsaw learning and its modified forms. This study aimed to see the effectiveness of the four-step jigsaw learning and the Jigsaw learning in improving students' argumentation skills about the concept of salt hydrolysis. This study was conducted with 2 classes of 11 grade students of SMAN 7 Kerinci Jambi. Some 53 students in total were purposively recruited and participated in this experiment. Concurrent embedded mixed method with two-group pretest-posttest control group design was used in this study. The results of independent t-test showed that $4 \mathrm{SJ}$ was more effective than the Jigsaw class $(t=2.668 ; \mathrm{p}$-value $=0.01<0.05)$. It was supported by the $\mathrm{n}$-Gain of $4 \mathrm{SJ}$ which was 0.71 and the $n$-Gain of jigsaw was 0.67 . Two factors that influenced the differences in students' argumentation skills were observed; these included the difference in learning duration and the intensiveness in conducting the argumentation debate.
\end{abstract}

Keywords: argumentation ability, four-step jigsaw, jigsaw, salt hydrolysis

\section{Introduction}

Science is one of the materials that can determine students to solve problems. One example of science that has many applications in problem-solving is chemistry. Students classify chemistry into difficult subjects because of abstract concepts that students must absorb in a short time. In the learning process, students are more likely to learn by memorizing rather than actively seeking their understanding of chemical concepts to produce their concepts. According to Matuk (2016) to understand the concept correctly, students need to develop abstract, critical, and analytical thinking skills including the ability to argue.

Argumentation ability is the ability to give reasons or opinions based on clear facts. Toulmin formulates argumentation skills into 6 components which include the ability to 
make claims, data, warrants, backing, qualifier, and rebuttal. Argumentation can train students in using thinking skills and add a deep understanding of an idea or idea (Pritasari et al. 2016). By being trained in argumentation, students can strengthen their understanding. Thus, students can gain a strong foundation in understanding a concept completely and correctly.

Based on the results of interviews with chemistry teachers at SMAN 7 Kerinci, it is known that students' argumentation skills are still low. The low ability to argue can be seen from the number of students who make statements without being can show scientific evidence and reasons that connect these statements and scientific evidence. For example, when students are given a phenomenon about "Which one dissolves faster, one tablespoon of sugar dissolved in $250 \mathrm{ml}$ of hot water or $250 \mathrm{ml}$ of plain water?" students gave the statement "sugar dissolved in hot water" and when asked why they could not answer. This indicates that students' argumentation skills are still lacking, where students are only able to make claims without any reason connecting statements and scientific evidence. Argumentation is used to strengthen a claim based on evidence and logical reasons (Witri et al. 2020).

To help develop students' argumentation skills, a learning model is needed that can help overcome these problems. The conditions for the formation of argumentation skills is the creation of a learning atmosphere that stimulates students to carry out argumentative activities. According to Matuk (2016), argumentation skills can be trained with a cooperative learning model that contains an argumentative syntax and provides opportunities for students to check the completeness of their arguments.

The cooperative model that has been used to improve argumentation skills is the learning model Argument-Driven Inquiry (ADI) used by Kurniasari \& Setyarsih (2017). The results showed that the argumentation ability of students using the ADI learning model was better than before using the learning model. Then the problem based learning ( $P B L)$ learning model conducted by Junaini et al. (2020) said that the PBL learning model could improve students' argumentation skills. The research that has been carried out by Rahayu et al. (2018) in their research that applies the Think Talk Write (TTW) model to improve argumentation skills (Harahap et al. 2018; Purba et al. 2018; Pakpahan et al. 2021). In the conclusion of the research, it is said that the TTW model can improve students' argumentation skills.

In addition, Effendi-Hasibuan et al. (2019) have used the jigsaw, TSTS, and DL learning models to improve the chemical argumentation skills of high school students in Jambi. These researchers found that these three models succeeded in increasing students' argumentation skills on the reaction rate material. However, of the three learning models used, the jigsaw learning model is more effective in improving students' argumentative abilities. The jigsaw type cooperative learning model is a learning model consisting of heterogeneous learning teams consisting of 4-5 students and teach student is responsible for mastering the learning material section and can teach the material section to team members (Slavin, 2010). The research of Lingga (2015) concluded that the jigsaw cooperative model can improve student learning outcomes. The jigsaw learning model can encourage students to be active and help each other in mastering the subject matter to achieve maximum achievement (Rusman, 2012). So the Jigsaw learning model is designed to increase students' sense of responsibility for their own learning and the learning of others. Thus, students are interdependent with 
one another and must cooperate cooperatively to learn the assigned material. However, according to Effendi-Hasibuan et al. (2020) in their research the jigsaw learning model that has been applied in several developing countries has obstacles in influencing the success of the implementation of cooperative learning. One of the obstacles in its implementation is the lack of time and teacher participation to provide guidance. Effendi-Hasibuan et al. (2020) have modified the jigsaw learning model to be a Four-step Jigsaw (4SJ). 4SJ only includes 4 steps, namely, introduction, focus group discussion, sharing group discussion, and class discussion/review.

Chemistry learning materials that can be used in the $4 \mathrm{SJ}$ and Jigsaw learning models to improve argumentation skills, one of which is salt hydrolysis. In the salt hydrolysis material, various concepts must be mastered by students such as determining the types of salt hydrolysis based on the acid-base forming, determining the nature of salt solutions, and determining the $\mathrm{pH}$ of salt solutions. Therefore, salt hydrolysis will be more easily understood by students if in the learning process students are more active in exchanging ideas with other students, where students can be more independent in constructing information. In addition, difficulties in this material can be caused because students are still not actively involved in constructing their knowledge by involving students' argumentation skills. Based on the problems above, the researcher wants to see the effectiveness of the 4SJ and Jigsaw learning models in improving students' argumentation skills on the salt hydrolysis material. The purpose of the study: To determine the improvement and differences in students' argumentation skills using the 4SJ and Jigsaw learning models on salt hydrolysis material, and to find out the causes that affect the differences in students' argumentation abilities in the $4 \mathrm{SJ}$ and Jigsaw learning models.

\section{Methods}

Research was done at SMAN 7 Kerinci Jambi class XI IPA on salt hydrolysis material for the 2020/2021 academic year. This research method is a concurrent embedded mix method. The design used in this study was a two-group pretest-posttest group design, in which two experimental classes were selected and then pretest and posttest were given to both classes. The sampling technique was carried out by purposive sampling and obtained two sample classes, namely class XI IPA 4 as experimental class 1 and class XI IPA 3 as experimental class 2 . The data collection technique of this research was in the form of an essay test technique which included argumentation ability capable of providing 3 aspects, namely claims, data, reasons (Table 1), and observation sheets on the application of the 4SJ and Jigsaw learning models. The data analysis technique used is descriptive, normality test, homogeneity test, $\mathrm{N}$-gain test (Table 2), and independent test.

Table 2

\begin{tabular}{c|c}
\multicolumn{2}{c}{ Table of Division Category N-gain } \\
\hline N-gain Scores & Category \\
\hline$g>0.7$ & High \\
\hline $0.3 \leq \mathrm{g} \leq 0.7$ & Medium \\
\hline $\mathrm{g}<0.3$ & Low \\
\hline
\end{tabular}


Table 1

Criteria for Rubric Ability to Argument

\begin{tabular}{|c|c|c|c|}
\hline Level (score) & Claims & Evidence & Reasoning \\
\hline 5 & True & Relevant & True connect \\
\hline \multirow[b]{2}{*}{4} & \multirow[t]{2}{*}{ True } & Relevant & True, not \\
\hline & & Connected Irrelevant & True connect \\
\hline \multirow[b]{2}{*}{3} & \multirow[t]{2}{*}{ Right } & Relevant & False \\
\hline & & Irrelevant & True, not connecting \\
\hline \multirow[b]{2}{*}{2} & \multirow[t]{2}{*}{ Right } & Irrelevant & False \\
\hline & & False & True not connecting \\
\hline 1 & Right & False & False \\
\hline 0 & False & False & False \\
\hline
\end{tabular}

\section{Results and Discussion}

The results of this study indicate that the average argumentation ability of students in the $4 \mathrm{SJ}$ class is higher than the jigsaw class (Fig 1).

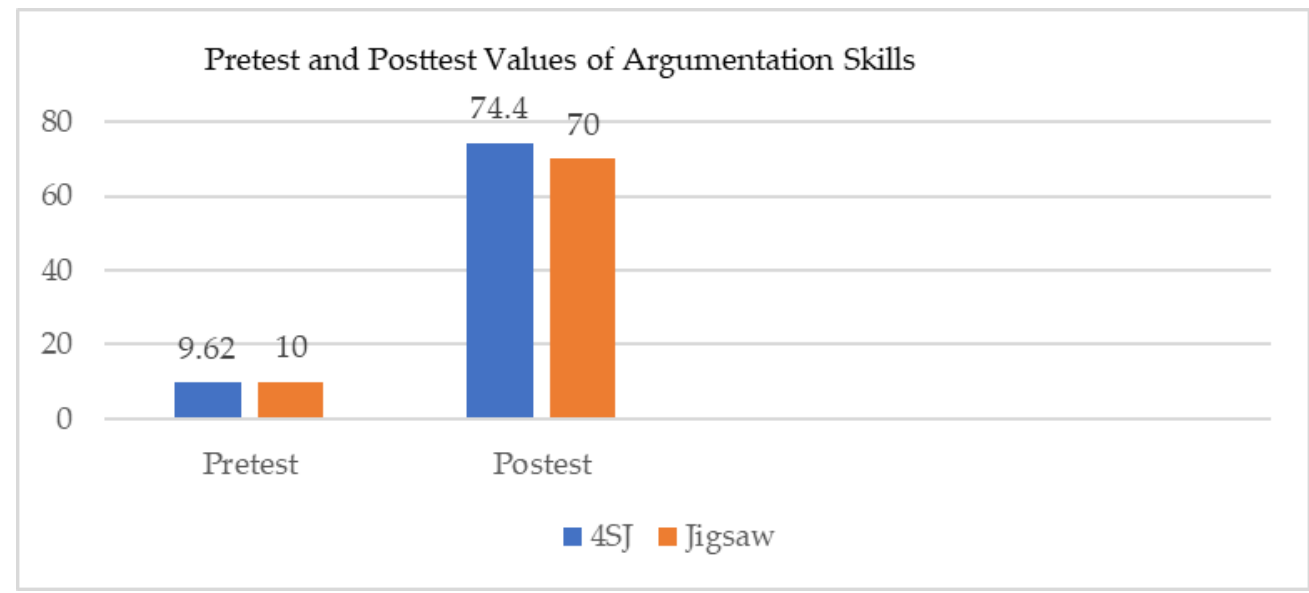

Fig 1. Pretest and posttest values of students' argumentation ability

Value of argumentation ability in the 4SJ and jigsaw class pretests is still low. In class 4SJ the argumentation ability of students with an average of 9.62 and in the jigsaw class the argumentation ability of students is an average of 10.00. This shows that the argumentation ability of students before treatment is the same. The argumentation ability of students can be seen from the results of the average pretest scores which are not much different. This is because students are not used to arguing. In addition, the low argumentation ability is because the teacher has not trained students to argue (Witri et al. 2020). Meanwhile, in the posttest scores, students' argumentation skills increased. It can be seen that the average value of the argumentation ability of the 4SJ graders is 74.44 and the jigsaw grade is 70.00 . According to Sarira et al. (2019), increasing students' scientific argumentation skills also increases students' cognitive abilities. Through argumentation skills, it is easier for students 
to form their concepts well. To see the difference in the level of argumentation in the two classes, it can be seen in the following figure (Fig 2).

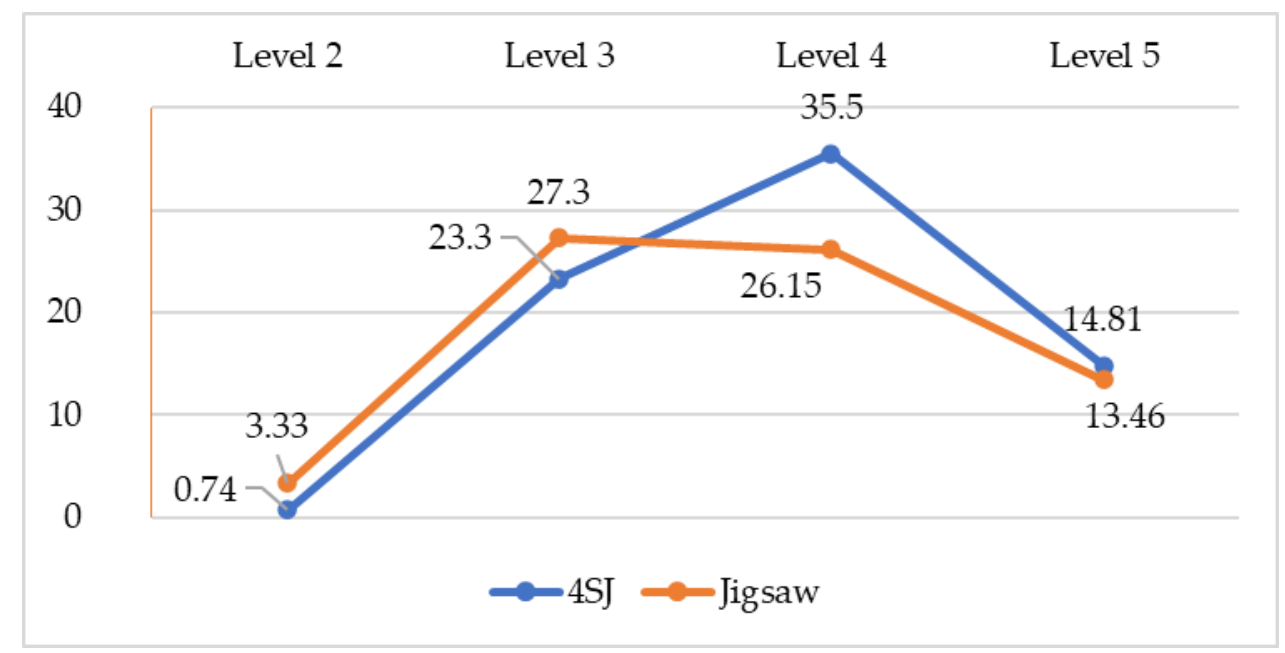

Fig. 2 Level of argumentation ability of students' posttest scores

Based on Figure 2, it can be seen that in grade 4SJ, students' argumentation ability has increased along with the increasing level of argumentation. Where the argumentation ability at level 3 is 23.3 , level 4 is 35.5 and at level 5 is 14.81 . Meanwhile, in the Jigsaw class, students' argumentation skills also increased. It can be seen that the level of students' argumentation at level 3 is 27.3 , level 4 is 26.15 and level 5 is 12.46 . From Figure 2 it can be seen that the argumentation ability of students is higher in grade $4 \mathrm{SJ}$ compared to the jigsaw. This can be seen from the percentage of higher argumentation levels at levels 4 and 5 in 4SJ grade which shows that most students can provide claims, data, and reasons. Meanwhile, in the Jigsaw class, students' argumentation skills are at levels 3 and 4, which indicates that students can provide claims and data but are still wrong or incorrect in giving reasons.

Furthermore, the N-gain test was carried out to see the increase in students' argumentation ability learning outcomes after being given treatment. The results of the $\mathrm{N}$ gain test can be seen in Table 3 .

Table 3

\begin{tabular}{c|c|c}
\multicolumn{3}{c}{ N-Gain Scores Test } \\
\hline Learning Model & N-Gain Scores & Category \\
\hline 4SJ & 0.71 & High \\
\hline Jigsaw & 0.67 & Medium \\
\hline
\end{tabular}

The $\mathrm{N}$-gain score for the class using the jigsaw learning model of 0.67 is included in the medium category. In the learning model that uses the 4SJ model, 0.71 is included in the high category (Lestari \& Mujib 2018). These results indicate that the jigsaw learning model is quite effective in improving students' argumentation skills on the salt hydrolysis material. While the 4SJ model is effective for improving students' argumentation skills on salt hydrolysis material. This can happen because in the learning process these two models have the opportunity to manage information and improve communication skills so that all students 
will be involved and will have a positive impact on student learning outcomes (EffendiHasibuan et al. 2019). However in the 4SJ class, the learning process is more effective than the jigsaw class because the syntax is shorter so that students have more time to discuss.

Next, the normality test was carried out on the pretest and posttest values of argumentation ability taken from the Shapiro-Wilk data used for the number of samples $<50$. The normality test data for the pretest value of argumentation ability can be seen in Table 4 .

Table 4

Normality test data of the pretest value of the argumentative ability

\begin{tabular}{l|r|r|r|r|r|r}
\hline \multirow{2}{*}{ Learning Model } & \multicolumn{3}{|c|}{ Kolmogorov-Smirnov $^{\text {a }}$} & \multicolumn{3}{c}{ Shapiro-Wilk } \\
\cline { 2 - 7 } & Statistic & \multicolumn{1}{c|}{ Df } & \multicolumn{1}{c|}{ Sig. } & \multicolumn{1}{c}{ Statistic } & \multicolumn{1}{c}{ df } & \multicolumn{1}{c}{ Sig. } \\
\hline Pretest_4SJ & .165 & 26 & .067 & .924 & 26 & .056 \\
\hline Pretest_Jigsaw & .154 & 26 & .116 & .924 & 26 & .056 \\
\hline
\end{tabular}

Based on Table 4, obtained significant value 4SJ class pretest scores of 0.56 and 0.56 jigsaw classroom. The significance value of the two classes $>0.05$ means that the pretest scores in both classes are normally distributed (Ross \& Willson, 2017). Based on table 5, the significance value of the $4 \mathrm{SJ}$ class is 0.245 and the jigsaw class is 2.10. The significance value of both classes is $>0.05$. So it can be concluded that the posttest scores of the two classes are normally distributed (Ross \& Willson, 2017). The following table normality test posttest value argument capability can be seen in Table 5 .

Table 5

Data Normality Test posttest argumentation ability

\begin{tabular}{l|r|r|r|r|r|r}
\hline \multirow{2}{*}{ Learning Model } & \multicolumn{3}{|c|}{ Kolmogorov-Smirnov $^{\mathrm{a}}$} & \multicolumn{3}{c}{ Shapiro-Wilk } \\
\cline { 2 - 7 } & Statistic & \multicolumn{1}{c|}{ Df } & \multicolumn{1}{c|}{ Sig. } & Statistic & \multicolumn{1}{c}{ df } & \multicolumn{1}{c}{ Sig. } \\
\hline Posttest_4SJ & .146 & 26 & .165 & .951 & 26 & .245 \\
\hline Posttest_Jigsaw & .135 & 26 & $.200^{*}$ & .948 & 26 & .210 \\
\hline
\end{tabular}

The difference in the ability of the student's argument can be seen from the pretest and posttest of both classes. The pretest and posttest scores of the two classes were then carried out by an independent $t$-test. The results of the independent $t$-test pretest and posttest for class 4SJ and jigsaw can be seen in Table 6 and Table 7.

From Table 6, obtained sig. (2-tailed) of $(0.729<0.05)$, it can be interpreted that the argumentation ability pretest scores of students in class $4 \mathrm{SJ}$ and Jigsaw have no difference (Ross \& Willson, 2017). This shows that the argumentation ability of students in class 4SJ and Jigsaw is the same before doing the treatment. Furthermore, in table 7, it can be seen that the results of the independent t-test the posttest value of the students' argumentation ability scores sig. (2-tailed) of $(0.010<0.05)$. From these data, it can be concluded that there is a significant difference between the posttest scores of students' argumentation skills in class 4SJ and class Jigsaw (Ross \& Willson, 2017).

The reason for the differences in the argumentation abilities of students in $4 \mathrm{SJ}$ and Jigsaw classes is the difference in learning syntax. In a jigsaw learning syntax that is too long, students are less effective in discussions because in the jigsaw learning process, the learning syntax is often not resolved. According to Dalimunthe et al. (2017) model Jigsaw 
also has weaknesses, namely the delivery of subject matter by members of the expert group to the homegroup is less effective (still awkward), time is limited, the class atmosphere is easy to get noisy with the formation of groups, and there are still students who passively only depend on other students. So that the information obtained by students is not complete or not yet completed. In line with the research of Hasibuan et al. (2020) his research said that the jigsaw learning model that has been applied in several developing countries has obstacles in influencing the success of the implementation of cooperative learning. One of the obstacles in its implementation is the lack of time.

Table 6

Data on the results of the independent t-test from

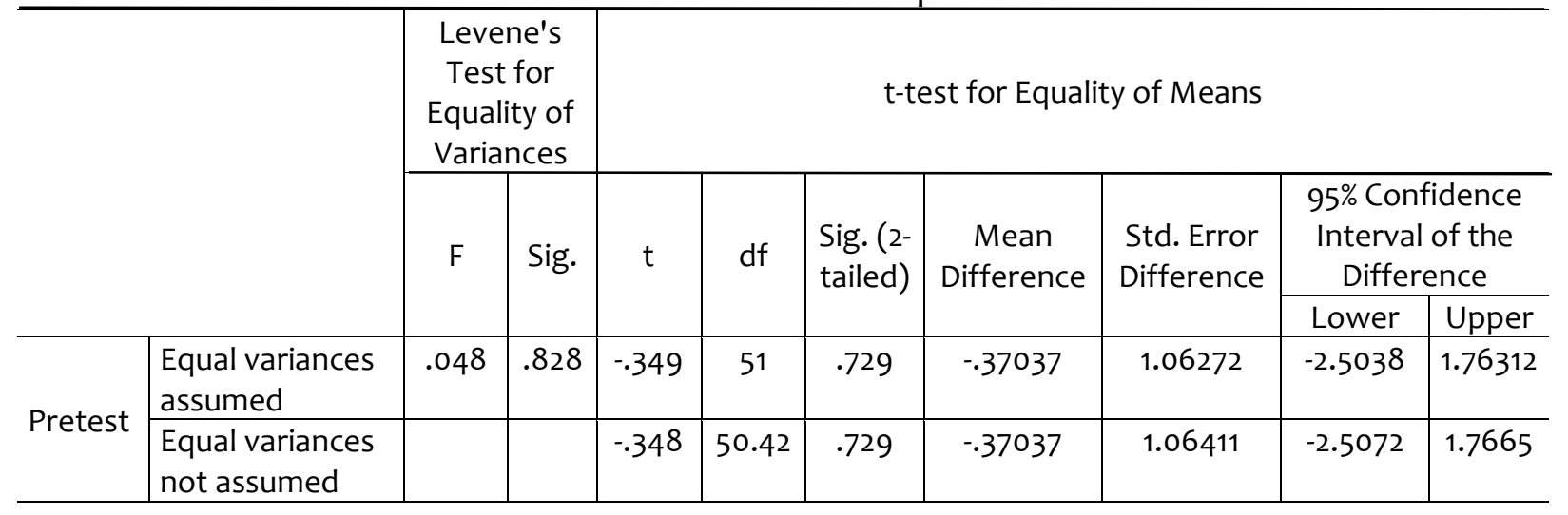

Table 7

Data on the results of the t-test independent of the Posttest

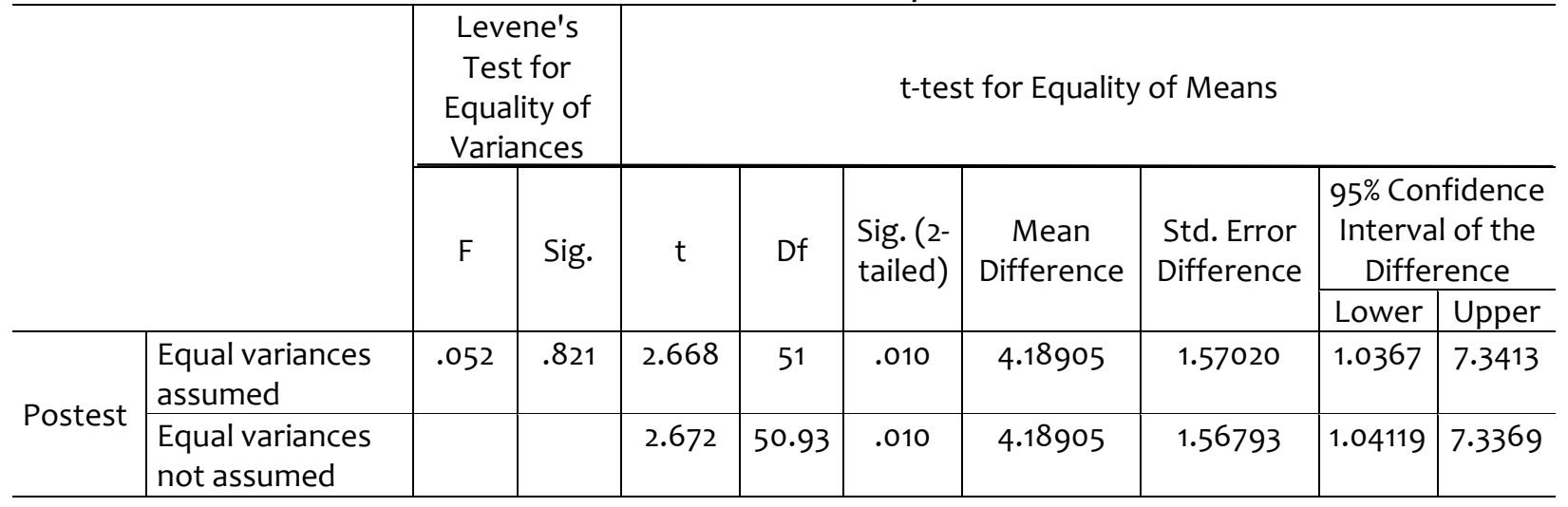

The 4SJ learning model is a modified learning model from the jigsaw learning model. The 4SJ learning model is a simplification of complex jigsaw syntax. 4SJ only includes 4 steps, namely, introduction, focus group discussion, sharing group discussion, and class discussion/review. The 4SJ syntax is shorter than the previous jigsaw learning model (Hasibuan et al. 2020). In learning in class 4SJ students have more time to discuss with their groups because the syntax is not too much. So that the discussion time with the group is more intensive. According to Effendi-Hasibuan et al. (2019) in the jigsaw learning process students have the opportunity to manage information and improve communication skills so 
that all students will be involved and will have a positive impact on student learning outcomes.

\section{Conclusion}

Based on the results of the research and discussion, the following conclusions can be drawn: the application of the $4 \mathrm{SJ}$ and Jigsaw learning models to the salt hydrolysis concept can improve the argumentation ability of students at SMAN 7 Kerinci. However, 4SJ was more effective than the jigsaw learning. The different learning syntaxes between the two classes was the major factor influencing the difference in the students' argumentation skills; in which the $4 \mathrm{SJ}$ students was more intensive in discussion than the Jigsaw students.

\section{Acknowledgments}

Researchers would like to thank all parties who have participated, especially chemistry teachers and students of class XI IPA SMAN 7 Kerinci for their contributions and cooperation in this research.

\section{References}

Dalimunthe, M. (2017). The differences in student learning outcomes by using the jigsaw type cooperative method and the recitation method on hydrocarbon material. Jurnal Pendidikan Kimia, 9(3), 336-340. DOI:10.24114/jpkim.v9i3.8383

Effendi-Hasibuan, M.H., Harizon, H., Ngatijo, N., Fuldiaratman, F., \& Sulistyo, U. (2019). Promoting indonesian secondary school students' argumentation skills in the concept of chemistry reaction-rate: A comparative effect of three cooperative learning strategies. Journal of Physic: Conference Series, 1317, 012143.DOI: 10.1088/1742-6596/1317/1/012143.

Harahap, N.M., Hutabarat, W., \& Silaban, S. (2018). The effect of model problem based learning (PBL) assistance of prezi media on student learning outcomes in colloid materials. Advances in Social Science, Education and Humanities Research, 200, 456-458

Hasibuan, M. H. E., Fuldiaratman, F., Dewi, F., Sulistiyo, U., \& Hindarti, S. (2020). Jigsaw learning strategy in a diverse science-classroom setting: Feasibility, challenges, and adjustment. Jurnal Cakrawala Pendidikan, 39(3), 733-745. DOI:10.21831/cp.v39i3.30634

Junaini, J., Rusdi, M. R. M., \& Muslim, M. (2020). Penerapan model problem based learning untuk meningkatkan kemampuan argumentasi matematika peserta didik kelas X SMAN 2 kota Jambi. PHI: Jurnal Pendidikan Matematika, 4(1), 21-31. DOl:10.33087/phi.v411.82

Kurniasari, I. S., \& Setyarsih, W. (2017). Penerapan model pembelajaran argument driven inquiry (ADI) untuk melatihkan kemampuan argumentasi ilmiah siswa pada materi usaha dan energi. Jurnal Inovasi Pendidikan Fisika, 06(03), 171-174.

Lestari, Y., \& Mujib, M. (2018). Kemampuan berpikir kritis matematis melalui model education coins of mathematics competition (E-COC). Desimal: Jurnal Matematika, 1(3), 265-274.

Lingga, P. (2015). Upaya meningkatkan kreativitas siswa dalam pembelajaran biologi melalui penerapan model pembelajaran kooperatif type Jigsaw di SMA Negeri 2 Balige. Jurnal Pendidikan Kimia, 7(2), 31-39. 
Matuk, C. (2016). The learning affordances of augmented reality for museum exhibits on human health. Museums \& Social Issues, 11(1), 73-87. DOI:10.1080/15596893.2016.1142815

Pakpahan, D. N., Situmorang, M., Sitorus, M., \& Silaban, S. (2021). The Development of Project-Based Innovative Learning Resources for Teaching Organic Analytical Chemistry. Advances in Social Science, Education and Humanities Research, 59, 782-788.

Purba, D. N., Damanik, M., Silaban, S., \& Simatupang, L. (2018). The difference of student 's activities and learning outcome with problem based learning using macromedia flash and handout. Jurnal Pendidikan Kimia, 10(3), 403-408. DOI:10.24114/jpkim.v10i3.12704

Pritasari, A. C., Sri, D., \& Riezky, M. P. (2016). Peningkatan kemampuan argumentasi melalui penerapan model problem based learning pada siswa kelas X MIA 1 SMA Batik 2 Surakarta Tahun Pelajaran 2014/2015. Jurnal Pendidikan Biologi, 8(1), 1-7.

Rahayu, M., Kurniati, T., \& Yusup, I. R. (2018). Keterampilan argumentasi pada pembelajaran materi sistem respirasi manusia melalui penerapan model pembelajaran think talk write. Jurnal Bio Educatio, 3(2), 50-58.

Ross, A., \& Willson, V. L. (2018). Basic and advanced statistical tests: Writing results sections and creating tables and figures. Springer.

Rusman. (2011). Model-model pembelajaran: Mengembangkan profesionalisme guru. Jakarta: PT Rajagrafindo Persada.

Sarira, P. M., Priyayi, D. F., \& Astuti, S. P. (2019). Hubungan Argumentasi ilmiah dan hasil belajar kognitif pada penerapan model problem based learning (PBL). Edu Sains: Jurnal Pendidikan Sains dan Matematika, 7(2), 1-10. DOI:10.23971/eds.v7i2.1258

Slavin, R. E. (2010). Cooperative learning teori, riset dan praktik. Bandung: Nusa Media.

Witri, E., Ngatijo, N., \& Effendi-Hasibuan, M. H. (2020). Development of electronic student worksheets based on toulmin argumentation patterns to improve argumentation skills in basic acid materials. Jurnal Pendidikan Kimia, 12(3), 116-123. DOl:10.24114/jpkim.v12i3.21160 